Bangladesh J. Plant Taxon. 26(1): 97-106, 2019 (June)

(C) 2019 Bangladesh Association of Plant Taxonomists

\title{
ANATOMICAL INVESTIGATION OF FOUR TAXA OF SCUTELLARIA ALBIDA L. (LAMIACEAE)
}

\author{
Ersin Minareci ${ }^{1}$, Sinem PekÖnÜr, Canan ÖZdemir, Mehmet ÇiçeK ${ }^{2}$ \\ AND OKAN KOCABAȘ \\ Manisa Celal Bayar University, Faculty of Science and Letters, Department of Biology, \\ Muradiye-Manisa-Turkey
}

Keywords: Scutellaria albida; Four taxa; Anatomy; Turkey.

\begin{abstract}
The root, trunk and leaf anatomy of four taxa of Scutellaria albida namely, S. albida subsp. albida, S. albida subsp. velenovskyi, S. albida subsp. colchica and S. albida subsp. condensata were examined. The aim is to determine whether these characters can be used for systematic purposes. The roots displays a typical stele structure in all studied taxa. But their number of pith rays are different in each taxa. The stems of $S$. albida taxa have square like transection, collateral vascular bundles, parenchymatous pith and show 1-2 layered epidermis coated with thick cuticle. S. albida subsp. condensata has papillate epicuticular wax on its stem cuticle layer. In all taxa angular collenchyma, and cambium forming phloem outward and xylem inward are observed. The leaves are hypostomatic, have single rowed epidermis coated with thick cuticle and show dorsiventral mesophyll in all studied taxa. S. albida subsp. velenovskyi has echinate epicuticular wax on its leaf cuticle layer, but the others have smooth cuticle layer. The midrib shows one collateral bundles in all taxa but the shape of median veins of the leaf blade show variation in each taxa. Some of the anatomical characters viz. the number of pith rays of roots, the number of palisade parenchyma layer, plant cuticles covered by wax, the shape of median veins of the leaf blade and stomata index, provide information of taxonomical significance for these taxa.
\end{abstract}

\section{Introduction}

Scutellaria L. (skullcap), a member of the Lamiaceae family, has approximately 300 species and this genus prefers living in temperate climates (Paton, 1990a). Scutellaria is viable plant for every continent except for Antarctica with its main centre of diversity in Irano-Turanianregion of Asia. Eastern Mediterranean and the Andes are secondary center of the diversity (Paton, 1990b, Bruno et al., 2002). Turkey is accepted as the gene center of Lamiaceae family to which the Scutellaria genus belongs (Başer, 1993). Scutellaria is represented by twenty-four species, thirteen subspecies and one hybrid in the flora of Turkey. Thirteen (\%41) of them are endemic to Turkey (Çiçek, 2008)

Scutellaria has been used in spices, fragrances, traditional and folk medicines in different parts of the world for centuries. They are well known among people as powerful medicinal herbs which are mild relaxants that affect the neural and muscular-skeletal systems (Werker et al., 1985; Duke, 1989; Zargari, 1990; Stojakowska and Kisiel, 1999; Graham et al., 2000; Kim et al., 2001; Hui et al., 2002; Weber, 2009). A lot of Scutellaria species were studied in hygiology. There are lots of scientists who studied their therapeutic activities, for example, inflammatory, antioxidant, anti-HIV, spasmolytic, anti-anticonvulsant, antifungal, antidiarrhea, anticancer, antipyretic, antibacterial, and antiviral activities (Chou et al., 2003; Shang et al., 2010).

\footnotetext{
${ }^{1}$ Corresponding author, Email: ersinminareci@gmail.com

${ }^{2}$ Pamukkale University, Faculty of Science and Letters, Department of Biology, Denizli, Turkey.
} 
Scutellaria albida subsp. velenovskyi (Rech. f.) Greuter \& Burdet was considered as a different species in Turkish literature and has named as Scutellaria velenovskyi (Greuter et al., 1984). Çiçek (2008) considered as a polymorphism within the species because of geographic isolation of different populations. Few studies of detailed examination and the conflictions mentioned above lead us to study these four taxa anatomy; since anatomical characters play an important role in the taxonomical studies of medical plants (Agbagwa and Ndukwu, 2004; Kharazian, 2007).

In this study, anatomical structures of roots, stems and leaves of four taxa of Scutellaria albida namely, S. albida subsp. albida L., S. albida subsp. velenovskyi, S. albida subsp. colchica (Rech.f.) J.R. Edm. and S. albida subsp. condensata (Rech.f.) J.R. Edm. were examined and compared. The vegetative anatomy was proved to be an important source of additional characters for resolving taxonomic difficulties in Scutellaria albida. So, this study aims to clarify the questions on this polymorphic species and add new databases.

\section{Material and Methods}

Plant samples were collected between 2013 and 2014 from their natural environments during their flowering period (Table 1).

Table 1. The location and collection data of the material studiedfrom Turkey.

\begin{tabular}{|c|c|}
\hline Taxa & Specimen location and habitat \\
\hline S. albida subsp. albida & $\begin{array}{l}\text { Kastamonu: From Cide to Azdavay, between } 53 \mathrm{~km} \text {, Asarkaya tunnel } \\
\text { entry and exit, } 547 \mathrm{~m} \text {, rock hill, } \mathrm{N} 41^{\circ} 49.503^{\prime} \text { E } 033^{\circ} 24.035^{\prime} \text {; } \\
30.07 .2013\end{array}$ \\
\hline S. albida subsp. velenovskyi & $\begin{array}{l}\text { Aydın: Kuşadas1, Davutlar, Dilek Peninsula National Park, Kalamaki } \\
\text { stream, } 202 \mathrm{~m} \text {, dry river bed edges, N } 37^{\circ} 40^{\prime} 46.0^{\prime \prime} \text { E } 027^{\circ} 09^{\prime} 48.8^{\prime \prime} \text {; } \\
07.07 .2013\end{array}$ \\
\hline S. albida subsp. colchica & $\begin{array}{l}\text { Artvin: From Yusufeli to Artvin, between } 30 \mathrm{~km}, 444 \mathrm{~m} \text {, rock slopes, } \\
\text { N } 40^{\circ} 55.979^{\prime} \text { E } 041^{\circ} 46.192^{\prime} ; 21.07 .2014\end{array}$ \\
\hline S. albida subsp. condensata & $\begin{array}{l}\text { Bitlis: From Van to Tatvan, between } 23 \mathrm{~km}, 1679 \mathrm{~m} \text {, Quercus sp. } \\
\text { slopes, N } 38^{\circ} 28^{\prime} 32^{\prime \prime} \text { E } 042^{\circ} 31^{\prime} 02^{\prime \prime} ; 19.07 .2014\end{array}$ \\
\hline
\end{tabular}

Plant samples were stored in the Manisa Celal Bayar University Herbarium. The taxonomic descriptions of the species were made according to Paton (1990a). The plant specimens were kept in $70 \%$ alcohol. The paraffin wax method (Algan, 1981) was used in order to fix the materials. Then the prepared paraffin blocks were sectioned with a Leica RM2125RT rotary microtome. In order to make structural characterization, the transverse sections (5-10 $\mu \mathrm{m}$ thick) were stained with safranin-fast green (Johansen, 1940). Using entellan, the slides were fixed. Finally slides were looked over with Olympus BX50 research microscope and photographs were taken on Leica DW 3000 with a Leica DFC 295 camera. Ten peripheral slides were prepared for each taxon and the stomata index was calculated (Meidner and Mansfield 1968).

\section{Results and Discussion}

\section{Anatomy of roots}

The outermost surface of root's transverse sections are made up of the periderm's cells which are squashed or breaking up in all investigated taxa. There is a multi-layered parenchymatic cortex which has compactly arranged, rectangular, oval or orbicular parenchymatic cells adjacent to the 
peridermis. Endodermis layer is seen clearly only in S. albida subsp. condensata (Fig. 1D). Pericycle located adjacent to the endodermis is sporadically divided with supporting tissue members in $S$. albida subsp. condensata. Above the phloem of all taxa, there is a sclerenchymatical sheath. The root of S. albida subsp. velenovskyi has irregular layered sclerenchymatical cells scattered throughout the cortex (Fig. 1B). There is small phloem region in the roots except for $S$. albida subsp. condensata which has large phloem region and the members of the phloem are seen clearly. 1-3 layered cambium rings are hardly visible and indistinguishable for all taxa of S. albida. A very large area of the transverse section occurs with the component of xylem in all investigated taxa. Trachea members are circular or hexagonal and they are regularly settled in increasingly accurate diameter from the centre to the cortex with the exception of $S$. albida subsp. condensata (Fig. 1) because its vessels are irregularly placed. The central vessels are larger than peripheral vessels. Pith rays of $S$. albida subsp. albida and S. albida subsp. velenovskyi are 2-9 layered, $S$. albida subsp. colchica are 2-4 layered and $S$. albida subsp. condensata are 1-2 layered (Fig. 1). They are heterogeneous. The pith of all taxa investigated is occupied by xylem elements. Representative anatomical characters of four taxa investigated are summarised in Table 2.

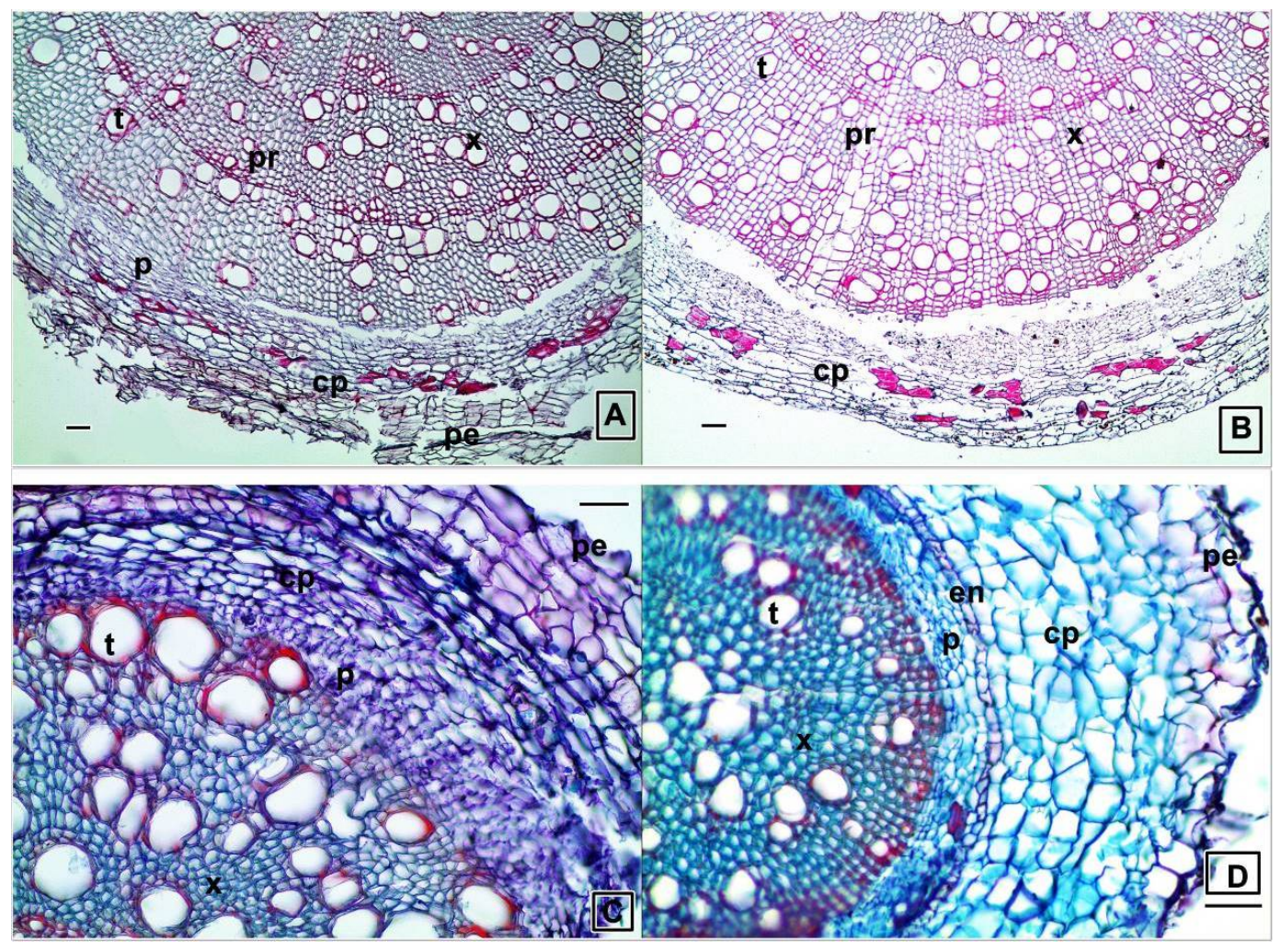

Fig 1. Cross section of the roots. A: S. albida subsp. albida, B: S. albida subsp. velenovskyi, C: S. albida subsp. colchica, D: S. albida subsp. condensata cp::cortex_parenchyma, x::xylem, en: endodermis,,pr::pith_rays, pe: periderm, ph:phloem, , t::trachea,_Bar: $50 \mu \mathrm{m}$ 
Table 2. Root features of four Scutellaria albida taxa.

\begin{tabular}{lcccc}
\hline $\begin{array}{l}\text { Root anatomical } \\
\text { characters }\end{array}$ & $\begin{array}{c}\text { S. albida subsp. } \\
\text { albida }\end{array}$ & $\begin{array}{c}\text { S. albida subsp. } \\
\text { velenovsky }\end{array}$ & $\begin{array}{c}\text { S. albida subsp. } \\
\text { colchica }\end{array}$ & $\begin{array}{c}\text { S. albida } \text { subsp. } \\
\text { condensata }\end{array}$ \\
\hline $\begin{array}{c}\text { Peridermis cell } \\
\text { width }(\mu \mathrm{m})\end{array}$ & $41.2 \pm 11.49$ & $34.05 \pm 10.66$ & $43.33 \pm 10.67$ & $31.35 \pm 8.90$ \\
length $(\mu \mathrm{m})$ & $15.8 \pm 4.35$ & $18.99 \pm 5.57$ & $19.91 \pm 3.69$ & $24.00 \pm 5.41$ \\
Parenchyma cell & & & & \\
width $(\mu \mathrm{m})$ & $42.53 \pm 14.23$ & $47.33 \pm 16.64$ & $37.87 \pm 7.70$ & $38.53 \pm 10.38$ \\
length $(\mu \mathrm{m})$ & $16.95 \pm 3.72$ & $26.00 \pm 7.02$ & $21.25 \pm 4.25$ & $25.43 \pm 6.75$ \\
Vessel $(\mu \mathrm{m})$ & $40.22 \pm 13.95$ & $50.19 \pm 14.74$ & $38.89 \pm 15.12$ & $27.10 \pm 8.53$ \\
Pith rays & $2-9$ & $2-9$ & $2-4$ & $1-2$ \\
\hline
\end{tabular}

Anatomy of stems

Transverse section of the stem is square like in four taxa of this species. Epidermis of all investigated taxa of this paper are coated with a thick cuticle layer. At the corner of S. albida subsp. condensata the cuticle layer is very thick. Furthermore, on the cuticle layer of it, papillate epicuticular wax is evident (Fig. 2). But papillate epicuticular wax has not been observed on others cuticle layers. The epidermal structure consist of 1-2 layered rectangular, oval or squarish cells. These cells are tabular. Limited number of stomata set into the epidermis. On the surface of the protective tissue of four taxa of S. albida, there are plenty of hairs most of which are glandular. Adjacent to the epidermal cells, there are multi-layered lamellar and lacunar collenchyma cells at the corners of the stems of all taxa. The cortex region is very narrow in all taxa and composed of irregular ovoidal, circular like or squashed parenchymatic cells with intercellular spaces. Measurements of these cells and the number of layers are given in Table 3. The sclerenchyma cells (1-3 layers) cover vascular bundles both at the corners and also between the corners of the stem. But, the sclerenchyma cells are indistinguishable between the corners of $S$. albida subsp. condensata. All vascular bundles located at the corners of stems of S. albida taxa are next to each other; yet, bundles between the corners in the stems are separated from each other by parenchymatic cells. At the corners, the vascular bundles are larger than the bundles between corners for all the taxa. Their cambiums are hardly visible. The stem of all taxa investigated in this paper have large pith which are composed of orbicular or hexagonal parenchymatic cells and there are intercellular spaces. The diameter of the cells in the centre of the pith is quite larger than of the cells located under the vascular bundle on four taxa of this species (Fig 3).

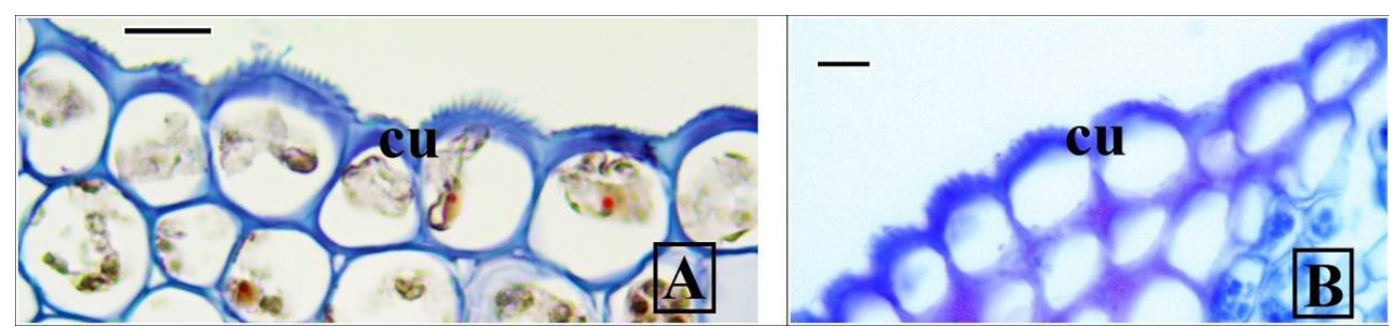

Fig. 2A: Cross-section of the leaf of S. albida subsp. velenovskyi, B: Cross-section of the stem of S. albida subsp. condensata. cu: cuticle with epicuticular wax. Bars: $10 \mu \mathrm{m}$ 
Table 3. Stem features of four Scutellaria albida taxa.

\begin{tabular}{lcccc}
\hline $\begin{array}{l}\text { Stem anatomical } \\
\text { characters }\end{array}$ & $\begin{array}{c}\text { S. albida subsp. } \\
\text { albida }\end{array}$ & $\begin{array}{c}\text { S. albida subsp. } \\
\text { velenovsky }\end{array}$ & $\begin{array}{c}\text { S. albida subsp. } \\
\text { colchica }\end{array}$ & $\begin{array}{c}\text { S. albida subsp. } \\
\text { condensata }\end{array}$ \\
\hline $\begin{array}{l}\text { Epicuticular wax } \\
\text { Epidermis cell }\end{array}$ & absent & Absent & absent & papillate \\
$\quad$ width $(\mu \mathrm{m})$ & $23.11 \pm 5.68$ & $12.40 \pm 3.28$ & $20.08 \pm 3.1$ & $20.87 \pm 6.80$ \\
$\quad$ length $(\mu \mathrm{m})$ & $15.02 \pm 2.60$ & $17.50 \pm 2.52$ & $15.46 \pm 3.42$ & $12.57 \pm 1.98$ \\
Cortex thickness & $218.12 \pm 13.02$ & $257.63 \pm 7.22$ & $182.00 \pm 7.96$ & $263.81 \pm 15.89$ \\
in the corner $(\mu \mathrm{m})$ & & & & \\
Cortex thickness in the & $59.31 \pm 20.02$ & $52.35 \pm 9.87$ & $118.33 \pm 12.79$ & $94.14 \pm 18.25$ \\
marginal $(\mu \mathrm{m})$ & & & & \\
Number of cortex layer & $3-6$ & $3-8$ & $5-8$ & $6-10$ \\
Corner collenchyma & $66.09 \pm 3.24$ & $105.11 \pm 34.24$ & $51.06 \pm 12.12$ & $103.10 \pm 8.61$ \\
thickness $(\mu \mathrm{m})$ & & & & \\
Vascular bundle & & & & \\
Phloem length $(\mu \mathrm{m})$ & $18.01 \pm 2.47$ & $24.20 \pm 8.95$ & $27.41 \pm 5.98$ & $46.15 \pm 12.76$ \\
Xylem length $(\mu \mathrm{m})$ & $206.88 \pm 44.61$ & $223.74 \pm 33.62$ & $100.9 \pm 29.21$ & $198.13 \pm 35.62$ \\
Trachea size $(\mu \mathrm{m})$ & $23.24 \pm 5.28$ & $40.96 \pm 11.50$ & $22.08 \pm 4.54$ & $26.39 \pm 6.42$ \\
Pith cell size $(\mu \mathrm{m})$ & $95.69 \pm 25.09$ & $92.02 \pm 36.99$ & $71.76 \pm 31.17$ & $101.89 \pm 37.85$ \\
\hline
\end{tabular}

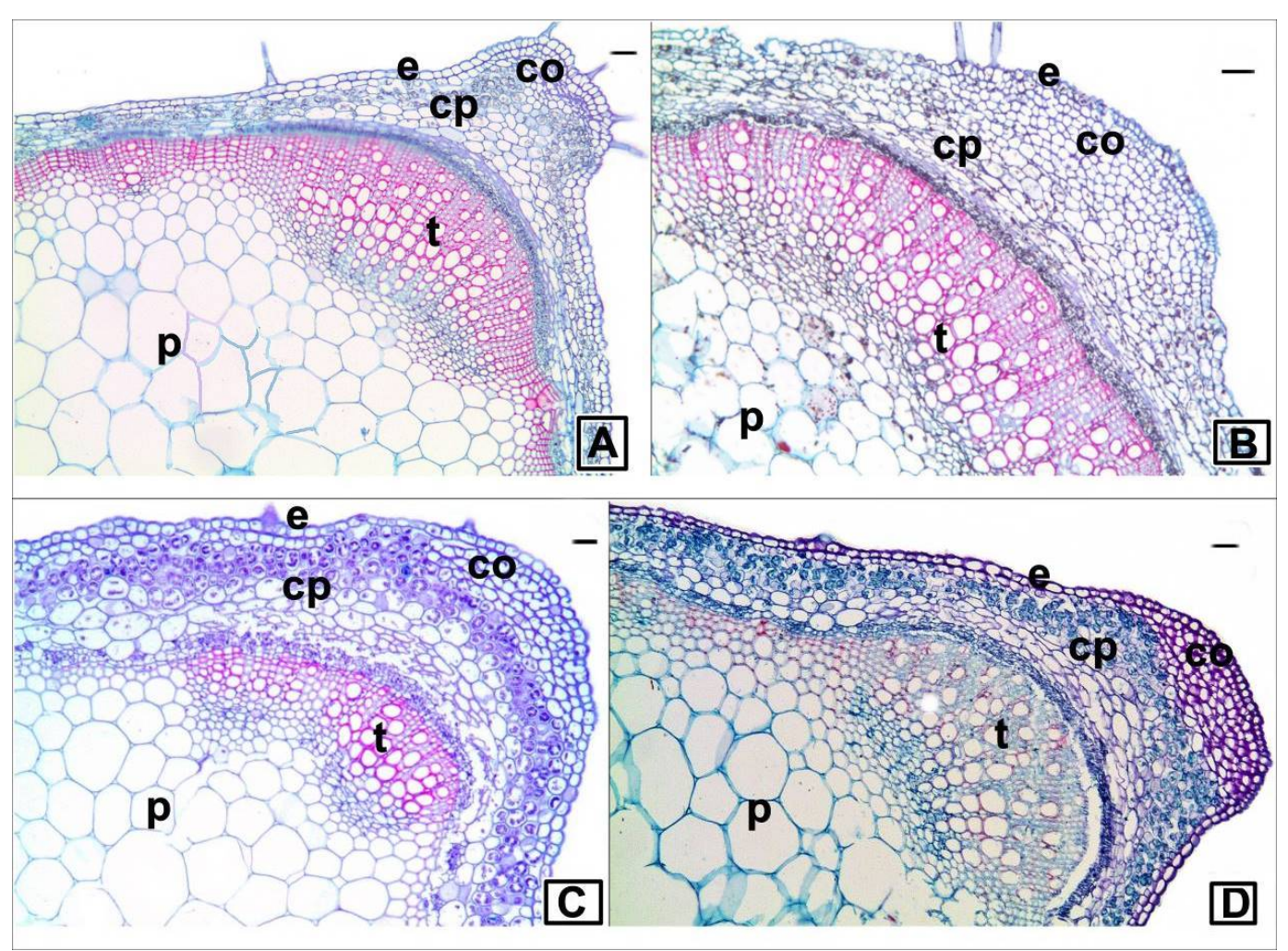

Fig. 3. Cross-section of the stems. A: S. albida subsp. albida, B: S. albida subsp. velenovskyi, C: S. albida subsp. colchica, D: $S$. albida subsp. condensata. co: collenchyma, cp: cortex parenchyma, e: epidermis, p: pith, t: trachea. Bar: $50 \mu \mathrm{m}$ 


\section{Anatomy of leaves}

Outer surface of the transverse section of the leaf blade is covered with a thick cuticle layer in the studied taxa. In their upper epidermis cuticle layers are thicker than those of the lower epidermis. Only S. albida subsp. velenovskyi has echinate epicuticular wax on the cuticle layer. The others have smooth cuticle layer. The glandular and eglandular hairs are located on both epidermises of all the studied taxa. Mesomorph stomata can only be seen in lower epidermis in the studied taxa. Their epidermis cells are rectangular, oval or squarish. Upper epidermal cells are large and tabular, but lower epidermal cells are small in four taxa of this species (Fig. 4). Their leaves are bifacial. The mesophyll is made up of elongated rectangular palisade parenchyma and isodiametric spongy parenchyma cells. Measurements and number of layers of these cells are given in Table 4. While the palisade paranchyma cells are arranged tightly and there are large intercellular spaces between the sponge parenchyma cells. There is one large arc-shaped vascular bundle in the center and vascular bundles are surrounded by a parenchymatic bundle sheaths in all studied taxa.

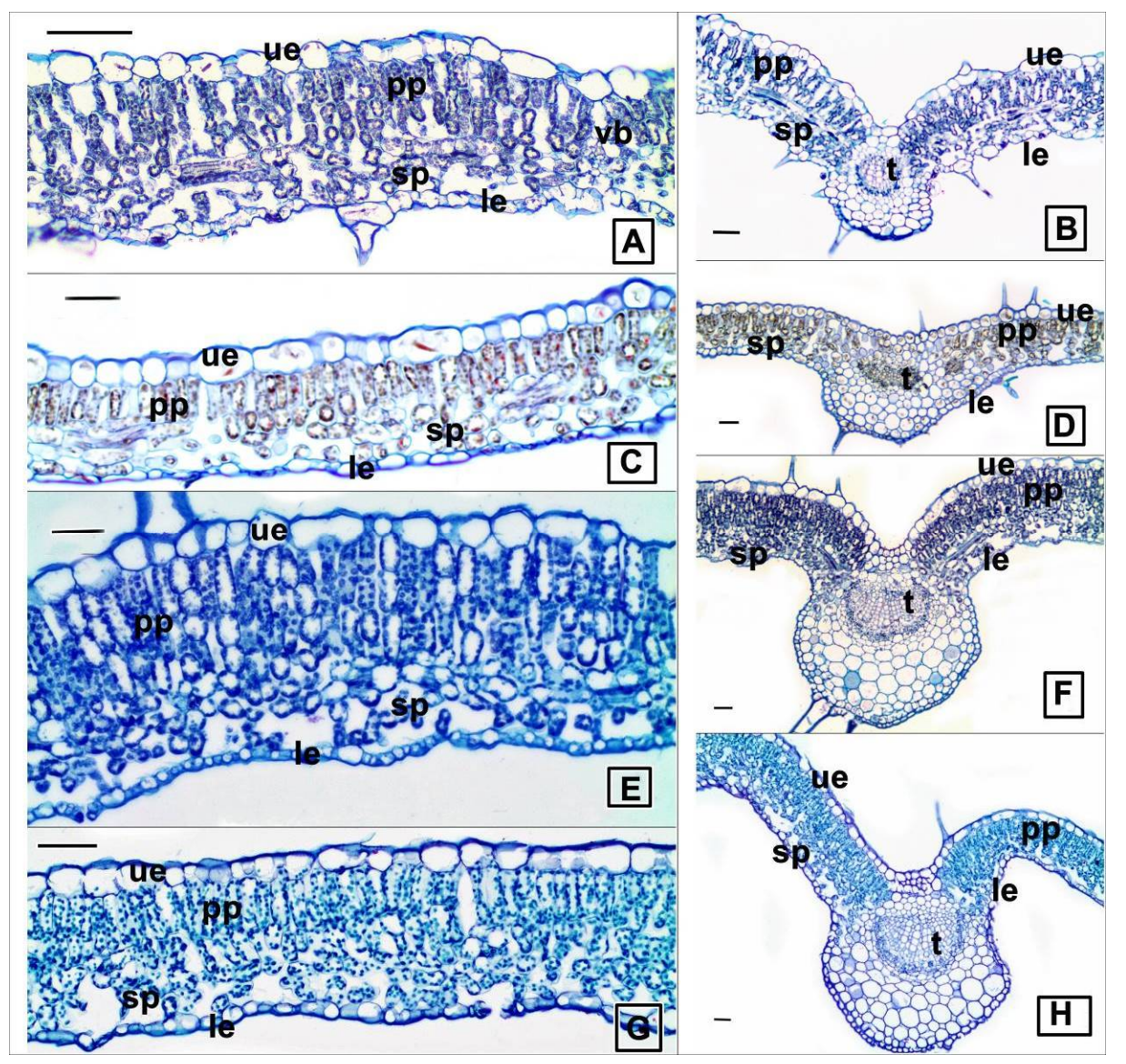

Fig. 4. Cross-section of the leaves. A,B: S. albida subsp. albida, C,D: S. albida subsp. velenovskyi, E,F: S. albida subsp. colchica, G,H:S. albida subsp. condensata. le: lower epidermis, pp: palisade parenchyma, sp: spongy parenchyma, t: trachea, ue: upper epidermis, vb: vascular bundle. Bars: $50 \mu \mathrm{m}$ 
Table 4. Leaf features of four Scutellaria albida taxa.

\begin{tabular}{lcccc}
\hline $\begin{array}{l}\text { Leaf anatomical } \\
\text { characters }\end{array}$ & $\begin{array}{c}\text { S. albida } \text { subsp. } \\
\text { albida }\end{array}$ & $\begin{array}{c}\text { S. albida } \text { subsp. } \\
\text { velenovsky }\end{array}$ & $\begin{array}{c}\text { S. albida } \text { subsp. } \\
\text { colchica }\end{array}$ & $\begin{array}{c}\text { S. albida } \text { subsp. } \\
\text { condensata }\end{array}$ \\
Upper cuticle $(\mu \mathrm{m})$ & $2.25 \pm 0.69$ & $3.41 \pm 0.59$ & $3.65 \pm 1.51$ & $2.40 \pm 0.47$ \\
Lower cuticle $(\mu \mathrm{m})$ & $\begin{array}{c}1.32 \pm 0.09 \\
\text { absent }\end{array}$ & $\begin{array}{c}3.71 \pm 1.76 \\
\text { Echinate }\end{array}$ & $\begin{array}{c}2.10 \pm 1.00 \\
\text { absent }\end{array}$ & $\begin{array}{c}2.89 \pm 0.67 \\
\text { absent }\end{array}$ \\
$\begin{array}{c}\text { Epicuticular wax } \\
\text { Upper epidermis }\end{array}$ & & & & \\
$\quad$ width $(\mu \mathrm{m})$ & $32.30 \pm 7.72$ & $30.13 \pm 15.09$ & $29.86 \pm 9.94$ & $30.73 \pm 8.73$ \\
$\quad$ length $(\mu \mathrm{m})$ & $24.39 \pm 3.41$ & $24.39 \pm 4.40$ & $28.62 \pm 5.05$ & $22.39 \pm 5.91$ \\
Lower epidermis & & & & \\
$\quad$ width $(\mu \mathrm{m})$ & $9.29 \pm 4.36$ & $16.00 \pm 6.39$ & $11.08 \pm 4.59$ & $13.12 \pm 4.82$ \\
$\quad$ length $(\mu \mathrm{m})$ & $8.35 \pm 2.29$ & $14.23 \pm 3.11$ & $11.58 \pm 2.63$ & $11.00 \pm 3.25$ \\
$\begin{array}{l}\text { Number of the } \\
\text { palisade cell line }\end{array}$ & $1-3$ & $1-2$ & $1-5$ & $1-3$ \\
Palisade cell & & & & \\
$\quad$ & & & & \\
$\quad$ width $(\mu \mathrm{m})$ & $11.72 \pm 2.18$ & $13.05 \pm 2.39$ & $18.11 \pm 3.03$ & $11.38 \pm 2.46$ \\
$\quad$ length $(\mu \mathrm{m})$ & $24.92 \pm 6.34$ & $29.07 \pm 6.03$ & $36.35 \pm 11.19$ & $30.33 \pm 9.31$ \\
Spongy cell & & & & \\
$\quad$ width $(\mu \mathrm{m})$ & $15.28 \pm 3.55$ & $17.90 \pm 4.28$ & $17.98 \pm 3.66$ & $14.49 \pm 3.95$ \\
length $(\mu \mathrm{m})$ & $12.91 \pm 2.81$ & $13.51 \pm 2.56$ & $16.22 \pm 3.39$ & $09.78 \pm 2.64$ \\
$\begin{array}{l}\text { Midrip trachea } \\
\text { Stomata index }\end{array}$ & $08.28 \pm 2.15$ & $02.23 \pm 0.44$ & $13.09 \pm 2.23$ & $15.07 \pm 4.09$ \\
\hline & $24.19 \pm 1.02$ & $25.97 \pm 0.93$ & $18.75 \pm 0.78$ & $18.51 \pm 0.85$ \\
\hline
\end{tabular}

Members of genus Scutellaria can live in various habitats. Many species become evident characteristics of moist environments (Metcalfe and Chalk, 1950). The smallest group of the genera, including Scutellaria albida, shows characteristic of arid environments such as xeromorphic characters. This study describes the characteristics of four subspecies obtained from anatomical investigations. The anatomy of four taxa of $S$. albida is broadly similar, but they also have some important distinctions among the taxa.

Metcalfe and Chalk (1950) studied the root anatomy in some of Lamiaceae taxa. They found that the roots of Lamiaceae family have $2-12$ or more-rowed pith rays. The present findings are congruent with the study made by Metcalfe and Chalk's (1950); Dinç et al. (2008); Baran and Özdemir (2009); Kahraman et al. (2010a,b); Celep et al. (2011). On the other hand, Lamium lycium Boiss. has 1-4 rowed rays (Baran and Özdemir, 2009). The pith rays of Salvia chrysophylla Stapfare composed of 1-24 rows (Kahraman et al., 2010a) and the pith rays of Salvia ballsiana (Rech.f.) Hedge are composed of 1-3 (-4) rows (Kahraman et al., 2010b). Lamium truncatum Boiss. has 1-4 rowed rays (Celep et al., 2011). The present study indicates that S. albida subsp. albida and S. albida subsp. velenovskyi have 2-9, S. albida subsp. colchica has 2-4 and S. albida subsp. condensata has 1-2 rows of ray cells (Fig. 1). Therefore, the pith rays number is useful discriminative characters for the subspecies of S. albida.

The mechanical supportable tissue is seen in the root of all taxa. These are sclerenchymatical cells located sporadically over the phloem. Moreover, roots of studied S. albida subsp. velenovskyi showed irregular layered sclerenchymatical cells scattered throughout the cortex. Gönüz and Özörgücü (1999) have obtained the similar results for the root of Origanumonites L.L.. Çobanoğlu (1988), Özdemir and Şenel (2001) have pointed the same sclerenchymatic ring and sheath on root of Salvia palaestina Bentham and S. forskahlei L. In the root of Scutellaria orientalis subsp. 
bicolor (Özdemir and Altan, 2005) sclerenchymatic ring and sheath is observed over phloem. The stems of all taxa of $S$. albida have sclerenchymatical sheath on phloem. Similar results were obtained for the stem of $S$. orientalis subsp. santolinoides (Hausskn. ex Bornm.) J.R.Edm. and $S$. orientalis subsp. bicolor (Özdemir and Altan, 2005). Meanwhile, the sclerenchyma is very important supportable tissue as recorded for species of Hypenia (Mart. ex Benth) Harley, one of the genera that grow in dry environments (Faria, 2008). S. albida taxa are arid environment plants. So, they have some sclerenchymatic cells in roots and in some parts of the stems.

Having square stem and features of endoderm are diagnostic characteristics of Lamiaceae members, as explained in this work for S. albida taxa and also for other species of this genus, such as Scutellaria agretis A. St.-Hil. ex Benth. (Oliveria et al., 2013), Scutellaria orientalis subsp. pinnatifida (Candan and Cali, 2012), S. orientalis subsp. bicolor and S. orientalis subsp. santolinoides (Ozdemir and Altan, 2005; Metcalfe and Chalk, 1950). Evident collenchyma in the four angles is frequently described for Lamiaceae (Cronquist, 1981). In the studied taxa, there are collenchymatic cells at each corner of the stems.

Stem epidermises of all investigated taxa are covered with a thick cuticle layer. At the corner of $S$. albida subsp. condensata the cuticle layer is thicker than the other taxa and papillate epicuticular wax is evident on this cuticle layer. Furthermore, outermost surface of the leaf of $S$. albida subsp. velenovskyi is covered with echinate epicuticular wax. The presence of epicuticular wax is noticed for the first time for the genus. Duarte and Lopes (2007) observed striate cuticle on Plectranthus neochilus Schltr (Lamiaceae) leaf blade. Plant cuticles are covered with waxes, many of which are of great systematic significance and it can be taxonomically useful characteristic for Scutellaria. Waxes are an essential structural element of the surface and of fundamental functional and ecological importance for the interaction between plants and their environments (Barthlott et al., 1998). Classification and terminology of epicuticular waxes are proposed based on high resolution SEM analysis of 13000 species of seed plants by Barthlott et al. (1998). But there is no record of epicuticular wax for the representatives of Scutellaria. The function of the epicuticular wax is known to be anti-adhesive, hardly wettable and preventing insect attachment (Barthlott et al., 1998).

Four taxa of $S$. albida have dorsiventral and hypostomatic leaves. However number of palisade layer shows some differences among the taxa. The mesophyll of S. albida subsp. colchica formed by 1-5 layers of palisade parenchyma. On the other hand, others formed fewer palisade layers (Table 4). Thick palisade tissue of mesophyll is considered as xerophytic characters. This feature was reported in Teucrium sandrasicum O. Schwarz (Dinç et al., 2008), T. montanum L. and T. polium L. (Dinç et al., 2011). Stomata may have found on one or both sides of the leaf blade in Lamiaceae family (Metcalfe and Chalk, 1950). S. albida has a hypostomatic leaf. Such leaf, it was also described in S. altissima L. (Thaler et al., 1992), S. orientalis subsp. bicolor and S. orientalis subsp. santolinoides (Ozdemir and Altan, 2005). Having hypostomatic leaf is also interpreted as xeromorphic type. S. albida exhibits diacyticstomata as predominantly other Lamiaceae family member (Metcalfe and Chalk, 1950). The stomata index showed variation in $S$. albida taxa. Stomata index of S. albida subsp. albida and S. albida subsp. velenovskyi are nearly same, and that of $S$. albida subsp. colchica and $S$. albida subsp. condensata are nearly same (Table 4). All studied taxa have projective median veins. However, when it is observed at the crosssections of taxa, the shape of median veins of the leaf blade show some differences (Fig. 4). S. albida subsp. albida has concave to flat median vein at abaxial side. S. albida subsp. velenovskyi has flat to concavemedian veinabaxial side. S. albida subsp. colchica and S. albida subsp. condensata have concave median vein at abaxial side. Therefore, these characters can also be used for distinguishing the subspecies in Scutellaria albida. 


\section{Acknowledgements}

The authors wish to thank Scientific Investigation Project to Coordinate of Manisa Celal Bayar University (Project No. FEF 2014-073) for financial support.

\section{References}

Agbagwa, O.I. and Ndukwu, B.C. 2004. The value of morphoanatomical features in the systematic of Cucurbita L. (Cucurbitaceae) species in Nigeria. Afr. J. Biotechnol. 3(10): 541-546.

Algan, G. 1981. Bitkisel Dokulariçin Mikroteknik. Fırat ÜniversitesiYayınları Elazı̆̆, Botanik No: 1 (in Turkish).

Baran, P. and Özdemir, C. 2009. The morphological and anatomical properties of Lamiumlycium (Lamiaceae), endemic to Turkey. Nordic J. Bot. 27: 388-396

Barthlott, W., Neinhuis, C., Cutler, D., Ditsch, F., Meusel, I., Theisen, I. and Whiltrud, H. 1998. Classification and terminology of plant epicuticular waxes. Bot. J. Linnean Soc. 126: 237-260.

Başer, K.H.C. 1993. Essential oils of Anatolian Lamiaceae: A profile. Acta Hortic. 333: 217-238.

Bruno, V., Castaldo, A., Centore, R., Sirigu, A., Sarcinelli, F., Casalboni, M. and Pizzoferrato, R. 2002. Second harmonic generation in polymers containing a new azo chromophore based on phenylnitrobenzoxazole. J. Polym. Sci. Part A Polym. Chem. 40: 1468-1475.

Candan, F. and Çali, I.Ö, 2012. Morphology and anatomy of Scutellaria orientalis L. subsp. pinnatifida Edmondson (Lamiaceae). 5th Water, Climate and Environment Conference Ohrid, Macedônia.

Celep. F., Kahraman. A., Atalay, Z. and Doğan, M. 2011. Morphology, anatomy and trichome properties of Lamium truncatum Boiss. (Lamiaceae) and their systematic implications. Aust. J. Crop Sci. AJCS 5(2): $147-153$.

Chou, T.C., Chang, L.P., Li, C.Y., Wong, C.S. and Yang, S.P. 2003.The antiinflammatory and analgesic effects of baicalin in carrageenan-evoked thermal hyperalgesia. Anesth Analg 97: 1724-1729.

Çiçek, M. 2008. Revision of the genus Scutellaria L. (Lamiaceae) in Turkey. Ph.D. Thesis Ankara University, Graduate School of Natural and Applied Sciences, Biology Department, Ankara 294 pp.

Çobanoğlu, D, 1988. Salvia palaesthina Bentham'ın (Lamiaceae) Morfolojikve Sitolojik Özellikleri. Doğa Bilim Dergisi: Biyoloji 12: 215-223 (in Turkish).

Cronquist. A, 1981. An integrated system of classification of flowering plants. Columbia University Press, New York.

Dinç, M, Duran, A., Pinar, M. and Öztürk, M. 2008. Anatomy, palynology and nutlet micromorphology of Turkish endemic Teucrium sandrasicum (Lamiaceae). Biologia 63(5): 637-641.

Dinç M, Doğu S, Doğru Koca A and Kaya B 2011. Anatomical and nutlet differentiation between Teucrium montanum and T. polium from Turkey. Biologia 66(3): 448-453.

Duarte, M.R. and Lopes, J.F. 2007. Stem and leaf anatomy of Plectranthus neochilus Schltr. Lamiaceae. Rev Bras Farmacogn 17: 549-556.

Duke, R.C., Persechini, P.M., Chang, S., Liu, C.C., Cohen, J.J. and Young, J.D. 1989. Purified perforin induces target cell lysis but not DNA fragmentation. The Rockefeller University Press, doi: 10.1084/jem.170.4.1451

Faria, M.T. 2008. Morfologia, anatomia, histoquímica e fitoquímica de espécies do gêneroHypenia (Mart. ex Benth) R. Harley-Lamiaceaeocorrentes no Cerrado de Goiás. Goiânia, Dissertação de Mestrado, Programa de Pós-graduaçãoemBotânica, Universidade Federal de Goiás. 205 pp.

Gönüz, A. and Özörgücü, B. 1999.An investigation on the morphology, anatomy and ecology of Origanum onites L. Turk. J. Bot. 23: 19-32.

Graham, J.G., Quinn, M.L., Fabricant, D.S. and Farnsworth, N.R. 2000. Plants used against cancer D an extension of the work of Jonathan Hartwell. J. Ethnopharmacol. 73: 347-377.

Greuter, W., Burdet, H.M. and Long, G. (eds) 1984. Scutellaria L. In: Med-checklist, Volume 3. Conservatoire et Jardin botaniques, Genève. pp. 341-346. 
Hui, K.M., Huen, M.S., Wang, H.Y., Zheng, H., Sigel, E., Baur, R., Ren, H., Li, Z.W., Wong, J.T. and Xue, H. 2002. Anxiolytic effect of wogonin, a benzodiazepine receptor ligand isolated from Scutellaria baicalensis Georgi. Biochem. Pharmacol. 64: 1415-1424.

Johansen, D.A. 1940. Plant Microtechnique, McGraw-Hill, New-York, 523 pp.

Kahraman, A., Celep, F. and Dogan, M. 2010a. Anatomy, trichome morphology and palynology of Salvia chrysophylla Stapf (Lamiaceae). South Afr. J. Bot. 76: 187-195

Kahraman, A., Dogan, M., Celep, F., Akaydin, G. and Koyuncu, M. 2010b. Morphology, anatomy, palynology and nutlet micromorphology of the rediscovered Turkish endemic Salvia ballsiana(Lamiaceae) and their taxonomic implications. Nordic Journal of Botany 28: 91-99.

Kharazian, N. 2007. The taxonomy and variation of leaf anatomical characters in the genus Aegilops L. (Poaceae) in Iran. Turk. J. Bot. 31: 1-9.

Kim, B.R., Kim, D.H., Park, R., Kwon, K.B., Ryu, D.G., Kim, Y.C., Kim, N.Y., Jeong, S., Kang, B.K. and Kim, K.S. 2001. Effect of an extract of the root of Scutellaria baicalensis and its flavonoids on aflatoxin B1 oxidizing cytochrome P450 enzymes. Planta Med. 67: 396-399.

Meidner, H. and Mansfield, T.A. 1968. Physiology of Stomata. McGraw-Hill. New York, 179 pp.

Metcalfe, R. and Chalk, L. 1950. Anatomy of the dicotyledons, 2 Vols. Oxford: Clarendon Press 1500 pp.

Oliveira, A.B., Mendonça, M.S. and Renata, M.S.A. Meira. 2013. Anatomy of vegetative organs of Scutellaria agrestis, a medicinal plant cultivated byriverine populations of the Brazilian Amazon. RevistaBrasileira de Farmacognosia 23: 386-397.

Özdemir, C. and Altan, Y. 2005. Morphological and anatomical investigations on endemic Scutellaria orientalis L. subsp. bicolor (Hochst.) Edmondson and subsp. santolinoides (Hausskn. ex Bornm.) Edmondson. Pak. J. Bot. 37(2): 213-226.

Özdemir, C. and Şenel, G. 2001.The Morphological, Anatomical and Karyological Properties of Salvia forskahlei L. (Lamiaceae) in Turkey. J. Econ. Taxon. Bot. 19: 297-313.

Paton, A. 1990a. A global taxonomic investigation of Scutellaria (Labiatae). Kew Bulletin, 45(3): 399-450.

Paton, A. 1990b. The phytogeography of Scutellaria L. Notes RBG Edinb. 46(3): 345-359.

Shang, X., Hea, X., Li, M., Zhanga, R., Fana, P., Zhanga, Q. and Jia, Z. 2010. The genus Scutellariaan ethnopharmacological and phytochemical review. J. Ethnopharmacol. 128: 279-313.

Stojakowska, A. and Kisiel, W. 1999. Secondary metab-olites from a callus culture of Scutellaria columnae. Fitoterapia 70: $324-325$.

Thaler, I., Gailhofer, M. and Pfeifhofer, H.W. 1992. Protein bodies in glandular hairs of Scutellaria altissima (Lamiaceae). Phyton. 31: 263-280.

Weber, 2009. New therapeutic aspects of flavones: The anticancer properties of Scutellaria and its main active constituents Wogonin, Baicalein and Baicalin- Cancer Treatment Reviews 35: 57-68.

Werker, E., Ravid, U. and Putievsky, E. 1985. Structure of glandular trichomes and identification of the main components of their secreted material in some species of the Labiatae. Israel Journal of Botany 34: $31-45$.

Zargari, A. 1990. Medicinal Plants, Vol. 4. Tehran University Publications, Tehran, pp. 148-150.

(Manuscript received on 2 February, 2019; revised on 5 may, 2019) 